\title{
Determination of $\mathbf{F}, \mathbf{S}_{\text {(total), }}$ and $\mathrm{Cl}$ in the Calcite Rich Limestone and Marbles by WD-XRF Spectrometry
}

\author{
Svetlana Ivanovna Shtel'makh \\ Institute of the Earth's Crust, SB RAS, 128 Lermontov St., Irkutsk 664033, Russia
}

\begin{abstract}
Determining the contents of $\mathrm{F}, \mathrm{S}_{(\text {total) }}$, and $\mathrm{Cl}$ in the studied samples of the limestone and marbles with high calcite contents was carried out by the nondestructive method of WDXRFS (Wavelength Dispersive X-ray Fluorescence Spectrometry). All measurements were performed in a vacuum condition using a WDXRF spectrometer S8 TIGER (Bruker AXS, Germany). The studied samples have wide ranges of $\mathrm{F}, \mathrm{S}_{\text {(total) }}$, and $\mathrm{Cl}$ contents, and high concentration of calcite $(89.5 \%-99 \%)$. Main objective of this research is to develop WDXRF (WD X-ray fluorescence) technique for the determination of $\mathrm{F}, \mathrm{S}_{\text {(total) }}$, and $\mathrm{Cl}$. The calculated values of the ILD (instrumental limit of the detection) were within the interval from 3 for $\mathrm{S}_{\text {(total) }}$ to 37 for $\mathrm{F} \mathrm{mg} / \mathrm{kg}$. The repeatability was found to be satisfactory with the relative standard deviations lower than $7 \%$.
\end{abstract}

Key words: X-ray fluorescence analysis, carbonate rocks with high calcite contents, limestone, marble, analytical figures of merit.

\section{Introduction}

$\mathrm{F}, \mathrm{S}_{(\text {total) }}$, and $\mathrm{Cl}$ are the volatile components for the reason that the concentration determination of these elements by solution chemistry methods is very difficult. Also, when determining of trace concentrations destructive methods are characterized by lower accuracy compared to the nondestructive method of WDXRFS (Wavelength Dispersive X-ray Fluorescence Spectrometry) [1].

It should be noted that investigation of the volatile components' concentration distribution in rocks is very important, since the volatile components take an active part in the formation of magmas of various compositions [2].

Also, determination of sulfur concentrations is necessary in the limestones, since it refers to harmful impurities [3].

$\mathrm{Cl}$ and $\mathrm{F}$ refer to harmful impurities in the compositions of the limestone meal and the marble powder as well as in the crushed marble. Currently, the limestone meal and the marble powder are widely

Corresponding author: Svetlana Ivanovna Shtel'makh, researcher, research fields: X-ray fluorescence analysis of rocks, sediments and soils, geochemistry and mineralogy. used in agriculture as additives to acidic soils in order to increase the $\mathrm{pH}$ value of soils. The crushed marble is used in landscape design most often as a decorative mulch of circles around the tree trunks. In case of high contents of $\mathrm{Cl}$ and $\mathrm{F}$ in the compositions of the limestone meal, the marble powder, and the crushed marble these harmful components enter in the soils and pollute them, and also have the negative impact upon the development of the plants $[4,5]$.

\section{Objects}

All studied samples of the calcite rich limestone and marbles were collected from a bottom part of dikes of granite-porphyry, andesite, trachyte composition of the Biliutinskiy deposit. This deposit is located in the Zaigraevskiy district of the Buryatia

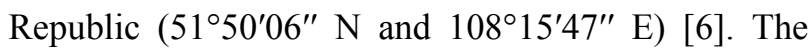
Biliutinskiy deposit is the active deposit of chemically pure limestone used for the production of calcium carbide $\left(\mathrm{CaC}_{2}\right)$. The revealed occurrence of the marbles indicates the impact of the contact metamorphism on the limestone. The studied limestone is characterized by a light-gray color, while the marbles are represented by five varieties with different colors 
depending on the content of impurities (the white marble, the white marble with pyrite veins, the light-gray marble with a blue tint, the dark-gray marble and the purple marble). The formation of pyrite which was identified in one of the varieties of the marble is associated with the hydrothermal stage of metamorphism. The mineral composition of the studied limestone and marbles was determined by X-ray diffraction analysis using a diffractometer DRON-3 (Russia). Measurements of the samples were performed under the following conditions: $25 \mathrm{kV}$ electric potential difference, $20 \mathrm{~mA}$ electric current intensity of the X-ray tube, the range of the $2 \theta$ angles from $3^{\circ}$ to $65^{\circ}$. Also, the $\mathrm{X}$-ray tube with a copper anode and the nickel filter were used. Identification of the minerals was performed using the obtained powder diffraction data [7]. The calcite $\left(\mathrm{CaCO}_{3}\right)$ content varies from $97 \%$ to $99 \%$ in the studied limestone and in most of the marbles, and the concentration of impurities does not exceed 3\% in their composition.

It was found that the concentration of impurities represented by talc, siderite and diopside is equal to $0.66 \%$ in the white marble. The content of impurities represented by pyrite and diopside increases to $1.8 \%$ in the white marble with pyrite veins. The concentration of impurities is equal to $2.6 \%$ in the dark-gray marble which is due to the presence of talc, amphibole and chlorite in its composition. The maximum content of impurities represented by hematite and quartz is equal to $10.48 \%$ in the purple marble in which the calcite concentration decreases to $89.5 \%$. It should be noted that the obtained data on the mineral composition of the studied samples are in good agreement with the data of silicate analysis [8]. The results of silicate analysis showed that $\mathrm{CaO}$ and $\mathrm{CO}_{2}$ are the dominant components in the chemical composition of all studied samples of the Biliutinskiy deposit. The concentrations of $\mathrm{CaO}$ and $\mathrm{CO}_{2}$ vary in the ranges: $49.53 \%-56.26 \%$ and $38.17 \%-43.12 \%$ in studied samples, respectively. The contents of $\mathrm{MgO}$ vary from $0.24 \%$ in the light-gray marble with a blue tint to $1.19 \%$ in the white marble with pyrite veins. The absence of dolomite in the mineral composition of the studied samples and the relatively low concentrations of $\mathrm{MgO}$ in their chemical composition indicate that the limestone and marbles of the Biliutinskiy deposit were not affected by dolomitisation processes. The $\mathrm{CaO} / \mathrm{MgO}$ ratio varies from 46 in the white marble with pyrite veins to 234 in the light-gray marble with a blue tint (Table 1).

The greatest similarity in the chemical composition is observed between the light-gray limestone and the white marble and the light-gray marble with a blue tint. The concentration increase of $\mathrm{MgO}$ and $\mathrm{SiO}_{2}$ is established in the dark-gray and the purple marbles in contrast to the light-gray limestone and the light varieties of marbles. The maximum contents of $\mathrm{P}_{2} \mathrm{O}_{5}$, $\mathrm{Al}_{2} \mathrm{O}_{3}, \mathrm{SiO}_{2}, \mathrm{MnO}$, and $\mathrm{Fe}_{2} \mathrm{O}_{3 \text { (total) }}$ are established in the purple marble compared to the light-gray limestone and other varieties of marbles (Table 1). The similar increase in the contents of the foregoing oxides of chemical elements is associated with very high concentrations of impurities in the purple marble.

\section{Methodology}

\subsection{Samples Preparation for Analysis}

The selection of material for the analysis was performed by the quartering method. The sample preparation was performed in accordance with the requirements given in Ref. [9]. The selected samples were powdered manually in the agate mortars for $10 \mathrm{~h}$. For the elimination of a particle aggregation during the milling process a few drops of ethyl hydroxide of high purity were added.

Particle sizes of the powdered samples were defined using a laser particle-size analyzer "Analysette 22" COMPACT (FRITSCH, Germany). Particle sizes did not exceed $75 \mu \mathrm{m}$ and varied from 10 to $61 \mu \mathrm{m}$. The prepared samples weighing $1 \pm 0.0001 \mathrm{~g}$ were used for the determination of the concentrations of $\mathrm{S}_{\text {(total) }}, \mathrm{Cl}$ and F. The prepared samples were pressed into tablets 
Table 1 The chemical composition (\%) of the studied samples of the limestone and marbles of the Biliutinskiy deposit (the analysis was carried out by N. N. Ukhova, T. V. Popova, and E. G. Koltunova).

\begin{tabular}{|c|c|c|c|c|c|c|}
\hline Component & $\begin{array}{l}\text { Light-gray } \\
\text { limestone }\end{array}$ & $\begin{array}{l}\text { Light-gray marble } \\
\text { with a blue tint }\end{array}$ & White marble & $\begin{array}{l}\text { White marble } \\
\text { with pyrite veins }\end{array}$ & Dark-gray marble & Purple marble \\
\hline $\mathrm{SiO}_{2}$ & $<0.05$ & 0.12 & 0.15 & 0.23 & 1.46 & 4.88 \\
\hline $\mathrm{TiO}_{2}$ & $<0.02$ & $<0.02$ & $<0.02$ & $<0.02$ & $<0.02$ & $<0.02$ \\
\hline $\mathrm{Al}_{2} \mathrm{O}_{3}$ & $<0.25$ & $<0.25$ & $<0.25$ & $<0.25$ & $<0.25$ & 0.28 \\
\hline $\mathrm{Fe}_{2} \mathrm{O}_{3 \text { (total) }}$ & 0.35 & $<0.25$ & $<0.25$ & 0.84 & 0.32 & 5.59 \\
\hline $\mathrm{MnO}$ & 0.04 & $<0.01$ & 0.03 & 0.06 & 0.04 & 0.23 \\
\hline $\mathrm{MgO}$ & 0.35 & 0.24 & 0.40 & 1.19 & 0.72 & 0.98 \\
\hline $\mathrm{CaO}$ & 55.32 & 56.26 & 55.16 & 54.97 & 54.86 & 49.53 \\
\hline $\mathrm{Na}_{2} \mathrm{O}$ & 0.02 & 0.03 & 0.05 & 0.08 & $<0.01$ & 0.03 \\
\hline $\mathrm{K}_{2} \mathrm{O}$ & $<0.01$ & 0.02 & 0.03 & 0.03 & 0.03 & 0.05 \\
\hline $\mathrm{P}_{2} \mathrm{O}_{5}$ & $<0.03$ & $<0.03$ & $<0.03$ & 0.07 & $<0.03$ & 0.09 \\
\hline $\mathrm{H}_{2} \mathrm{O}^{-}$ & 0.10 & $<0.01$ & 0.40 & $<0.01$ & 0.10 & 0.12 \\
\hline Loss on ignition & 0.89 & 0.38 & 1.10 & 0.35 & 0.78 & 0.52 \\
\hline $\mathrm{CO}_{2}$ & 42.84 & 43.12 & 42.57 & 42.70 & 42.10 & 38.17 \\
\hline$\sum$ & 99.91 & 100.17 & 99.89 & 100.52 & 100.41 & 100.47 \\
\hline $\mathrm{CaO} / \mathrm{MgO}$ & 158 & 234 & 138 & 46 & 76 & 51 \\
\hline
\end{tabular}

The symbol "<" means that the component concentration is less than detection limit.

$\mathrm{H}_{2} \mathrm{O}^{-}$is hygroscopic water.

Table 2 WDXRF measuring conditions.

\begin{tabular}{|c|c|c|c|c|c|c|c|}
\hline \multirow{2}{*}{$\begin{array}{l}\text { Analytical } \\
\text { line }\end{array}$} & \multicolumn{2}{|c|}{$2 \theta\left({ }^{\circ}\right)$} & \multirow{2}{*}{$-\mathrm{kV}$} & \multirow{2}{*}{$\mathrm{mA}$} & \multirow{2}{*}{$\begin{array}{l}\text { Collimator } \\
\left({ }^{\circ}\right)\end{array}$} & \multirow{2}{*}{$\begin{array}{l}\text { Analyzing } \\
\text { crystal }\end{array}$} & \multirow{2}{*}{ Detector } \\
\hline & Peak & Background & & & & & \\
\hline $\mathrm{FK}_{\alpha 1}$ & 38.265 & 42.787 & 30 & 60 & 0.46 & XS-55 & Flow Proportional Counter \\
\hline $\mathrm{SK}_{\alpha 1}$ & 75.749 & 76.521 & 40 & 50 & 0.23 & PET & Flow Proportional Counter \\
\hline $\mathrm{ClK}_{\alpha 1}$ & 65.463 & $\begin{array}{l}64.426 \\
66.426\end{array}$ & 40 & 50 & 0.23 & PET & Flow Proportional Counter \\
\hline
\end{tabular}

on a boric acid base with a diameter of $40 \mathrm{~mm}$ using the HERZOG HTP 40 semiautomatic press (Germany) with a pressure of $100 \mathrm{kN}$.

\subsection{WDXRF Set-Up}

All measurements were performed in a vacuum condition using a WDXRF spectrometer S8 TIGER (Bruker AXS, Germany).

This instrument is equipped with a $4 \mathrm{~kW}$ power $\mathrm{X}$-ray tube with a rhodium anode and a beryllium window of $75 \mu \mathrm{m}$ thickness [10]. Optimal instrumental measuring conditions were selected experimentally (Table 2). The Pentaerythrite (PET) analyzing crystal was selected for the determination of the concentrations of $\mathrm{S}_{\text {(total) }}$ and $\mathrm{Cl}$. It should be noted that a WDXRF spectrometer S8 TIGER with the PET crystal and a $0.23^{\circ}$ collimator were used for the determination of the sulfur concentrations in soils and plants in Ref. [11]. Also, the PET crystal was used for the determination of the concentrations of $\mathrm{P}_{2} \mathrm{O}_{5}, \mathrm{~S}_{\text {(total) }}$ and $\mathrm{Cl}$ in soils and sedimentary rocks in Ref. [12].

The contents of $\mathrm{F}$ were determined using the XS-55 crystal and a $0.46^{\circ}$ collimator (Table 2). Also, for the determination of $\mathrm{F}$ located in the long-wave region of the spectrum the electric potential difference of the $\mathrm{X}$-ray tube was reduced to $30 \mathrm{kV}$ (Table 2).

Measurement time of the analytical line and the

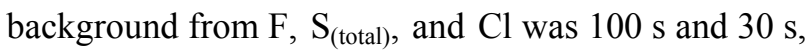
respectively. Processing the X-ray spectra, numerical peak separation, and the correction of the matrix effects were performed using the software SPECTRA $^{\text {plus }}[13]$. 


\subsection{RMs (Reference Materials)}

The RMs (ICRMs and HSRMs) with the high content of calcium oxide (more than 20\%) were selected to construct calibration curves and perform metrological studies. Carbonatite Bronnitsky (4390-88), Skarn Rock (4394-88), GPOS301 and GPOS302 (dolomitic limestones), GPOS303 (dolomite containing of feldspars 35.3\%), OOPE401 (calcareous ooze) were used $[14,15]$. The ICRMs and HSRMs of sediments and rock of various chemical composition were added to the calibration set of the foregoing RMs to provide a wider concentration range of $\mathrm{F}, \mathrm{S}_{\text {(total) }}$, and Cl. These RMs are OOKO202, OOKO203, OOKO204 (carbonatic-siliziclastic sediments), OOPE402 (siliceous silt), SGD1 (gabbro), ST1 and ST2 (traps), SGR1 (shale), SDC1 (mica schist), DNC1(dolerite), BIR1 (basalt). The similar solution was demonstrated in Ref. [16]. Also, the additional mixtures were prepared on the basis of the calcareous ooze, the carbonatic-siliziclastic sediments (OOPE401 and OOKO204), the calcareous spar (pure calcium carbonate), and oxide $\mathrm{SiO}_{2}$ (chemically pure) in various ratios. The additional mixtures were prepared manually with addition of ethyl hydroxide of high purity in the agate mortars. Each mixture was prepared for $3 \mathrm{~h}$. So, the carbonatic-siliziclastic sediments and the calcareous spar were mixed in ratios 1:1, 1:2, 2:1, 3:1. The carbonatic-siliziclastic sediments and oxide $\mathrm{SiO}_{2}$ were mixed in ratios 1:1, $1: 1.45,1: 3,1: 4,1: 5,1: 6$. The calcareous ooze and the carbonatic-siliziclastic sediments were mixed in ratios $1: 2,1: 3,1: 4$ and the calcareous ooze and the calcareous spar were mixed in ratios 1:1, 1:9, 2:1, 3:1 to obtain high concentrations of $\mathrm{Cl}$ (more than 1,000 $\mathrm{mg} / \mathrm{kg}$ ). It is connected with absence of the RMs with certified $\mathrm{S}$ and $\mathrm{Cl}$ contents in the ranges from 50 to $200 \mathrm{mg} / \mathrm{kg}$ and from 600 to $17,000 \mathrm{mg} / \mathrm{kg}$. These mixtures were used along with other RMs to construct calibration curves as in Ref. [17].

\section{Result and Discussions}

\subsection{X-Ray Spectra}

Fig. 1 shows the analytical lines spectra of $\mathrm{F}, \mathrm{S}$, and $\mathrm{Cl}$. The spectra were obtained using the "calcareous ooze" containing $\mathrm{CaO} 39.23 \%$. The contents of the determined elements in this $\mathrm{RM}$ are (in $\mathrm{mg} / \mathrm{kg}$ ): $\mathrm{F}-700, \mathrm{~S}_{\text {(total) }}-1900, \mathrm{Cl}-17,000$.

As seen from Fig. 1 , the $\mathrm{FeL}_{\alpha 1}\left(2 \theta=36.470^{\circ}\right)$ line overlaps on the $\mathrm{FK}_{\alpha 1}\left(2 \theta=38.265^{\circ}\right)$ line. Also, the influence of $\mathrm{AlK}_{\alpha 1}$-line and $\mathrm{MgK}_{\alpha 1}$-line in the second order of reflection on the $\mathrm{FK}_{\alpha 1}$-line is established. The influences of these lines on the $\mathrm{FK}_{\alpha 1}$-line and the
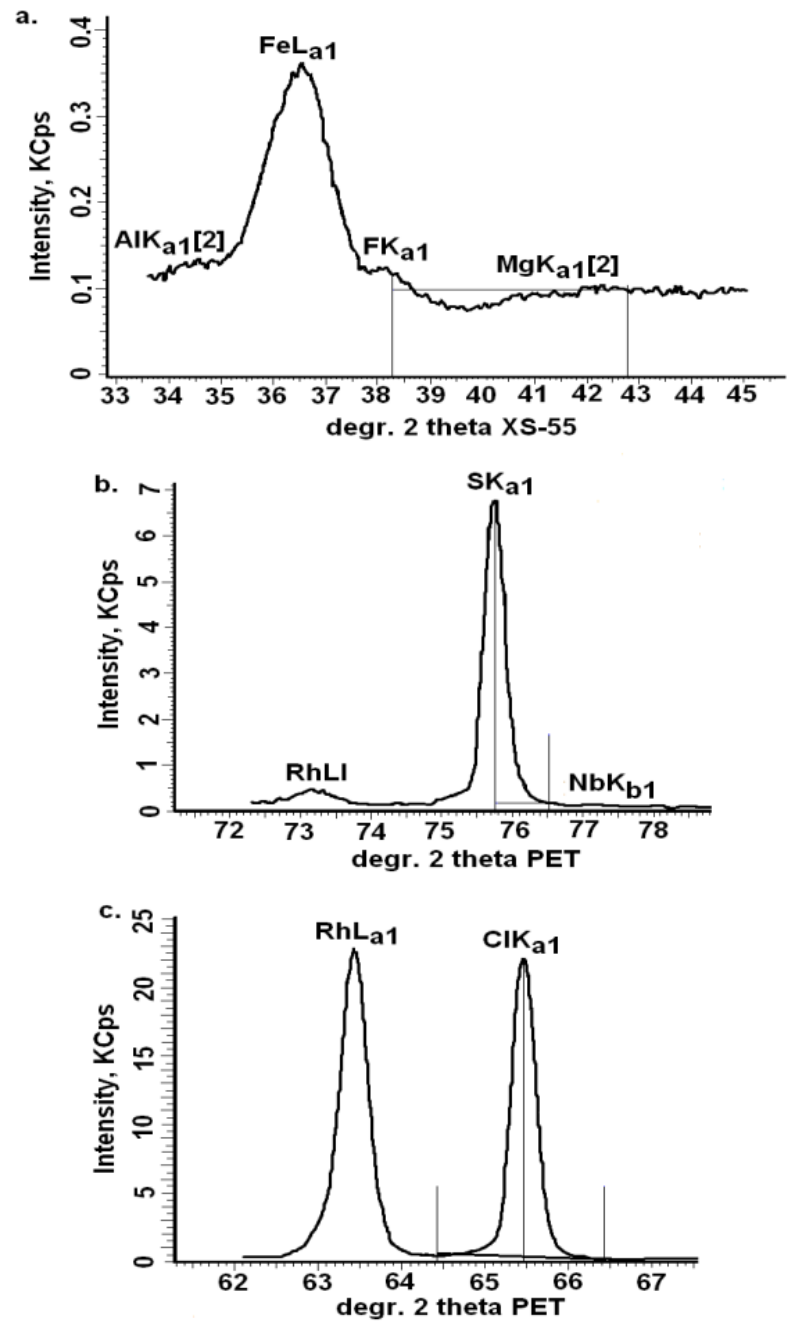

Fig. 1 a, b and c: XRF spectra of analytical lines of F, S, and $\mathrm{Cl}$. 
influence of the $\mathrm{RhL}_{\alpha \mathrm{I}-\mathrm{III}}$-lines on the $\mathrm{SK}_{\alpha 1}$-line and the $\mathrm{ClK}_{\alpha 1}$-line were taken into account to determine the concentrations of $\mathrm{F}, \mathrm{S}_{\text {(total) }}$, and $\mathrm{Cl}$. The influence of the $\mathrm{NbK}_{\beta 1}$-line on the $\mathrm{SK}_{\alpha 1}$-line is negligible.

\subsection{Quantitative Analysis}

The method based on the use of $\alpha$-coefficients was implemented to take into account the interelement influences in the software SPECTRA ${ }^{\text {plus }}$. The corrected concentrations were computed according to the equation:

$$
C_{\mathrm{i}}=m_{\mathrm{i}} I_{\mathrm{i}}\left(1+\sum_{j} \alpha_{\mathrm{ij}}^{\prime} I_{\mathrm{j}}\right),
$$

where $C_{i}$ and $I_{i}$ are concentration and intensity of the determined element analytical line corrected for background, $m_{i}$ is slope of the calibration curve, $I_{j}$ is matrix elements intensity corrected for background, $\alpha_{i j}$ is $\alpha$-coefficients used to account for matrix effects.

The coefficients for account of the contribution of the lines overlap were calculated using the equation:

$$
I_{i}^{-}=I_{i}+\sum_{\text {overlap }} k_{j} \cdot I_{j},
$$

where $I_{i}^{-}$is the corrected intensity for an $i$-th line, $I_{i}$ is the intensity of the determined element analytical line corrected for background (net intensity), $I_{j}$ is the intensity of the element that gives the interfering line, $k_{j}$ is the regression coefficient.

The scatter of points on the calibration curves was reduced significantly after accounting the matrix effects and the introduction of amendments for the lines overlap. Fig. 2 shows the calibration dependence for $\mathrm{Cl}$ in the range from 26 to $500 \mathrm{mg} / \mathrm{kg}$.

You can see that submitted calibration curve shows good linearity $\left(R^{2}=0.9902\right)$ (Fig. 2).

Table 3 presents the calibration data.

The $\mathrm{S}$ (standard deviation) characterizing a dispersion point around the calibration line was derived from linear regression equation using least-squares fit to provide minimum value of this one as in work [18]. The comparison indicated that the $\mathrm{S}$ values obtained using the fixed $\alpha$-coefficients were less than the $S$ values achieved without the matrix correction by 6.3-18.5 times (Table 3).

\subsection{Analytical Figures of Merit}

The ILD and the limit of determination of the WDXRF method (LDM) were calculated for F, $\mathrm{S}_{\text {(total) }}$, and $\mathrm{Cl}$ according to the recommendations from Refs. $[19,20]$. The ILD was defined as the minimum net intensity of an analyte, which can be detected by an instrument in a given analytical context with a $99.95 \%$ confidence level. It was calculated using the equation from Ref. [20]:

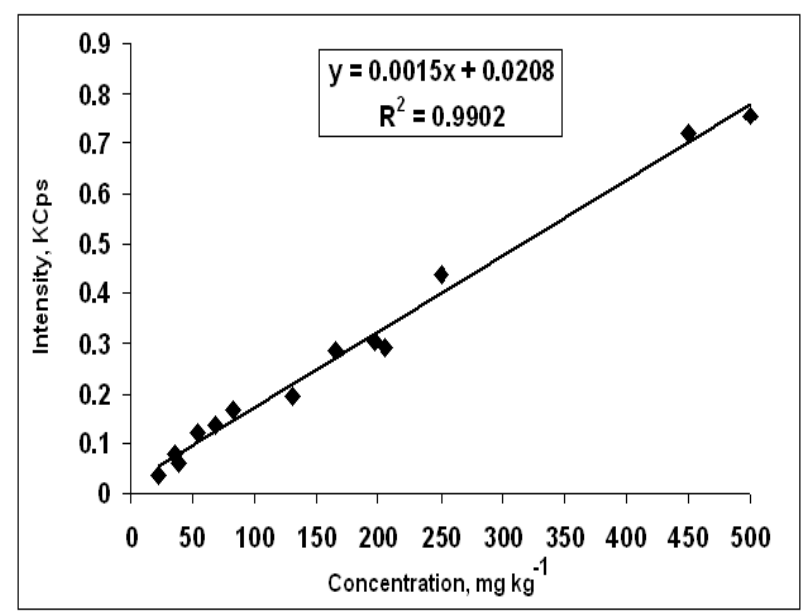

Fig. 2 The calibration curve for $\mathrm{Cl}$ in the range from 26 to $500 \mathrm{mg} / \mathrm{kg}$.

\begin{tabular}{|c|c|c|c|c|c|c|}
\hline \multirow{2}{*}{ Element } & \multirow{2}{*}{$\begin{array}{l}\text { Number } \\
\text { of the RMs }\end{array}$} & \multirow{2}{*}{$\begin{array}{l}\text { Calibration } \\
\text { range }(\mathrm{mg} / \mathrm{kg})\end{array}$} & \multirow{2}{*}{$\begin{array}{l}\text { Line overlap } \\
\text { correction }\end{array}$} & \multirow{2}{*}{$\begin{array}{l}\text { Influence coefficients } \\
\text { ( } \alpha \text {-correction) }\end{array}$} & \multicolumn{2}{|c|}{$\mathrm{S}^{\mathrm{a}}(\mathrm{mg} / \mathrm{kg})$} \\
\hline & & & & & $\overline{\mathrm{I}^{\mathrm{b}}}$ & $\mathrm{II}^{\mathrm{c}}$ \\
\hline $\mathrm{F}$ & 20 & $35-1,960$ & $\mathrm{FeL}_{\alpha 1}, \mathrm{AlK}_{\alpha 1}[2], \mathrm{MgK}_{\alpha 1}[2]$ & $\mathrm{CK}_{\alpha 1}, \mathrm{NaK}_{\alpha 1}, \mathrm{CaK}_{\alpha 1}, \mathrm{RhL}_{\alpha 1}$ & 104 & 37 \\
\hline $\mathrm{S}_{\text {(total) }}$ & 22 & $43-15,300$ & RhLI/Rayleigh & $\mathrm{CK}_{\alpha 1}, \mathrm{PK}_{\alpha 1}, \mathrm{ClK}_{\alpha 1}, \mathrm{CaK}_{\alpha 1}, \mathrm{FeK}_{\alpha 1}$ & 593 & 32 \\
\hline $\mathrm{Cl}$ & 30 & $26-17,000$ & $\mathrm{RhL}_{\alpha 1} /$ Rayleigh & $\mathrm{CK}_{\alpha 1}, \mathrm{PK}_{\alpha 1}, \mathrm{SK}_{\alpha 1}, \mathrm{SiK}_{\alpha 1}, \mathrm{CaK}_{\alpha 1}$ & 100 & 16 \\
\hline
\end{tabular}

Table 3 Calibration data obtained for $F, S_{(t o t a l)}$, and $\mathrm{Cl}$.

${ }^{\mathrm{a}}$ Standard deviation; ${ }^{\mathrm{b}}$ Without correction of the matrix effects; ${ }^{\mathrm{c}}$ With accounting of the matrix effects ( $\alpha$-correction). 


$$
\mathrm{ILD}=\frac{4.65}{S_{\mathrm{i}}} \sigma_{\mathrm{b}},
$$

where $S_{i}$ is sensitivity (Cps/concentration), $\sigma_{b}$ is the standard deviation calculated from several background intensity measurements $(n=10)$ performed in both sides of an analyte peak.

The calculated values of the ILD for the RM OOPE401 "calcareous ooze" are $3 \mathrm{mg} / \mathrm{kg}$ for $\mathrm{S}_{(\text {total })}, 14$ $\mathrm{mg} / \mathrm{kg}$ for $\mathrm{Cl}$ and $37 \mathrm{mg} / \mathrm{kg}$ for $\mathrm{F}$, respectively.

The LDM was defined as the smallest concentration of an analyte that can be reliably quantified by a given analytical method with a $95.4 \%$ confidence level [19, 20]. It was calculated from a series of ten replicate specimens $(n=10)$ prepared from the representative sample of the purple marble containing hematite and quartz using the equation:

$$
\mathrm{LDM}=2 \sqrt{\frac{\sum_{m=1}^{n}\left(C_{\mathrm{m}}-\bar{C}\right)^{2}}{n-1}} ; \bar{C}=\frac{\sum_{m=1}^{n} C_{\mathrm{m}}}{n} .
$$

The concentrations of $\mathrm{F}, \mathrm{S}_{\text {(total) }}$, and $\mathrm{Cl}$ and the obtained LDM values are shown in Table 4.

It can be seen, the LDM values do not exceed 15 $\mathrm{mg} / \mathrm{kg}$ for $\mathrm{F}, \mathrm{S}_{(\text {total) }}$, and $\mathrm{Cl}$. The RSD (relative standard deviation) values of the measurement results were calculated in order to test repeatability of the WDXRF technique as in Ref. [20]. Ten (10) tablets were prepared from the representative sample of the light-gray limestone and measured 1 time, after that 1 tablet from 10 was chosen and measured 10 times. The values of the RSD do not exceed $7 \%$ in all cases.

The accuracy of this WDXRF technique was checked by measuring the RMs OOKO204 (anomalous sediment) and AN-G (anorthosite). Table 5 presents the comparison of the results of the data obtained by the proposed WDXRF technique with the certified values.

You can see that the data obtained by the proposed WDXRF technique provide a good agreement with the certified values.

\subsection{Concentrations of $F, S_{(t o t a l)}$, and $\mathrm{Cl}$ in the Studied Samples}

The correlation relationships were identified between $\mathrm{F}, \mathrm{S}_{\text {(total) }}$, and $\mathrm{Cl}$ and oxides as a result of R-type cluster analysis (Fig. 3).

It can be seen, strong correlations were established between $\mathrm{S}_{(\text {total) }}, \mathrm{Cl}$ and $\mathrm{Na}_{2} \mathrm{O}$ in the first group. Also, strong correlation was established between $\mathrm{F}$ and $\mathrm{Al}_{2} \mathrm{O}_{3}$ in the second group. Straight-line correlations were identified between $\mathrm{F}$ and $\mathrm{MnO} \mathrm{Fe}_{2} \mathrm{O}_{3 \text { (total) }}$ in the same group because the correlation coefficient is 1.0. $\mathrm{CaO}$ and $\mathrm{CO}_{2}$ had formed the third group where straight-line correlation was established between these components, too.

Table 4 Limits of the determination $(\mathrm{mg} / \mathrm{kg})$ of the WDXRF method evaluated in the purple marble with hematite and quartz, $n=10$.

\begin{tabular}{lll}
\hline Element & Concentration $(\mathrm{mg} / \mathrm{kg})$ & LDM $^{\mathrm{a}}$ \\
\hline $\mathrm{F}$ & 620 & 13.7 \\
$\mathrm{~S}_{(\text {total })}$ & 68 & 1.1 \\
$\mathrm{Cl}$ & 114 & 8.5 \\
\hline
\end{tabular}

${ }^{\text {a }}$ The limit of determination of the WDXRF method.

Table 5 Concentrations $(\mathrm{mg} / \mathrm{kg})$ (mean \pm standard deviation, $n=6$ ) obtained for RMs OOKO204 (anomalous sediment) and

\begin{tabular}{|c|c|c|c|c|}
\hline \multirow{2}{*}{ Element } & \multicolumn{2}{|c|}{ OOKO204 } & \multicolumn{2}{|c|}{ AN-G } \\
\hline & $\overline{C_{\text {WDXRF }}}$ & $C_{\text {cert }}{ }^{\mathrm{a}}$ & $C_{\text {WDXRF }}$ & $C_{\text {cert }}{ }^{\mathrm{a}}$ \\
\hline $\bar{F}$ & $1,901 \pm 5$ & 1,900 & $122 \pm 4$ & 120 \\
\hline $\mathrm{S}_{\text {(total) }}$ & $498 \pm 5$ & 500 & $140 \pm 2$ & 140 \\
\hline $\mathrm{Cl}$ & $403 \pm 4.5$ & 400 & $302 \pm 3$ & 300 \\
\hline
\end{tabular}
AN-G (anorthosite) by the proposed WDXRF technique and the certified values for this RMs.

${ }^{\mathrm{a}}$ Certified value. 




Fig. 3 Correlation between $\mathrm{F}, \mathrm{S}_{(\text {total) }}$, and $\mathrm{Cl}$ and oxides in the studied samples of the limestone and marbles of the Biliutinskiy deposit.

Table 6 Mean concentrations $(\mathrm{mg} / \mathrm{kg})$ of $\mathrm{F}, \mathrm{S}_{(\mathrm{total})}$, and $\mathrm{Cl}$ in the studied samples of the limestone and marbles of the Biliutinskiy deposit.

\begin{tabular}{lllllll}
\hline Elements & $\begin{array}{l}\text { Light-gray } \\
\text { limestone }\end{array}$ & \multicolumn{2}{l}{$\begin{array}{l}\text { Light-gray marble } \\
\text { with a blue tint }\end{array}$} & White marble & $\begin{array}{l}\text { White marble } \\
\text { with pyrite veins }\end{array}$ & Dark-gray marble Purple marble \\
\hline $\mathrm{F}$ & $114 \pm 5$ & $50 \pm 1.5$ & $147 \pm 6$ & $180 \pm 6.3$ & $157 \pm 5$ & $620 \pm 12$ \\
$\mathrm{~S}_{(\text {total }}$ & $62 \pm 2.5$ & $59 \pm 0.8$ & $132 \pm 4.5$ & $2,880 \pm 25$ & $86 \pm 1.9$ & $68 \pm 3$ \\
$\mathrm{Cl}$ & $76 \pm 2$ & $83 \pm 2.5$ & $634 \pm 10$ & $876 \pm 12$ & $76 \pm 2.5$ & $114 \pm 3.5$ \\
\hline
\end{tabular}

Confidence intervals were computed at the confidence level $p=0.95$ and the number of the measurements $n=6$.

The dependence of the concentrations of $\mathrm{F}, \mathrm{S}_{\text {(total) }}$, and $\mathrm{Cl}$ on the content of impurities was established in the studied samples. Table 6 presents the mean concentrations $(\mathrm{mg} / \mathrm{kg})$ of $\mathrm{F}, \mathrm{S}_{(\mathrm{total})}$, and $\mathrm{Cl}$ in the studied samples of the limestone and marbles of the Biliutinskiy deposit. So, the maximum concentration of $F(620 \mathrm{mg} / \mathrm{kg})$ was found in the purple marble containing hematite and quartz. The maximum contents of $\mathrm{S}_{\text {(total) }}(2,880)$ and $\mathrm{Cl}(876)$ were identified in the white marble with pyrite veins.

It should be noted that the part of content $\mathrm{S}_{\text {(total) }}$ is associated with iron in pyrite $\left(\mathrm{FeS}_{2}\right)$ in the white marble with pyrite veins. High content of $\mathrm{Cl}$ (876 $\mathrm{mg} / \mathrm{kg}$ ) may be related to high concentration of $\mathrm{Na}_{2} \mathrm{O}$ $(0.08 \%)$ in this marble. Also, high content of $\mathrm{Cl}(634$ $\mathrm{mg} / \mathrm{kg}$ ) was established in the white marble containing $\mathrm{Na}_{2} \mathrm{O} 0.05 \%$.

The light-gray limestone and the marble light-gray with a blue tint are depleted in the volatile components ( $\mathrm{F}, \mathrm{S}_{\text {(total) }}$, and $\mathrm{Cl}$ ).

\section{Conclusions}

Development results of the WDXRF technique for quantitative determination of $\mathrm{F}, \mathrm{S}_{\text {(total) }}$, and $\mathrm{Cl}$ concentration in carbonate rocks are presented in the article. The instrumental limit of the detection, the limit of the determination, the repeatability and the accuracy of the WDXRF method were found to be satisfactory and illustrate the viability of the technique. The proposed WDXRF technique can be applied for analysis of carbonate rocks.

\section{Acknowledgments}

The author gratefully acknowledges analysts Z. F. Ushchapovskaia, candidate of geological and mineralogical sciences N. N. Ukhova, T. V. Popova, E. G. Koltunova for the help in the investigations of the carbonate samples by the X-ray diffraction and for the performance of the silicate analysis. Also, author thanks E. V. Khudonogova for assistance in the performance of the investigations. This study was 
performed using equipment located at the Center for Geodynamics and Geochronology (Institute of the Earth's Crust, SB RAS, Irkutsk, Russia).

\section{References}

[1] Evans, K. L., and Moore, C. B. 1980. "Combustion-Ion Chromato-Graphic Determination of Chlorine in Silicate Rocks." Analytical Chemistry 12: 1908-12.

[2] Kovalenko, V. I., Gimis, A. B., Naumov, V. B., Dorofeeva, B. A., and Yarmolyuk, V. V. 2007. "Volatiles in Basaltic Magmas of Ocean Island and Their Mantle Sources: I. Melt Compositions Deduced from Melt Inclusions and Glasses in the Rocks." Geochemistry International 45 (2): 105-22.

[3] Markovskiy, L. Y., Orshanskiy, D. L., and Pryanishnikov, V. P. 1952. Chemical Electrothermy. Moscow: State Scientific and Technical Publishing House of Chemical Literature, Leningrad. (in Russian)

[4] Konovalov, V. N., and Zarubina L. V. 2017. "The Influence of Chlorine-Containing Fertilizers on Metabolism of Spruce and Pine in the North Taiga Plant Communities." Forestry Journal 3: 100-13. (in Russian)

[5] Tandelov, Y. P. 2012. Fluorine in the Soil-Plant System, edited by Mineev, V. G. Krasnoyarsk: Krasnoyarsk City Printing House. (in Russian)

[6] Khubanov, V. B., Tsygankov, A. A., and Vrublevskaya, T. T. 2012. Late Paleozoic Bimodal Dike Series of Western Transbaikalia (Bilyutinsky Quarry). Excursion Guide for the II All-Russian Youth Conference "Geology of Transbaikalia”. Ulan-Ude: Publishing House of the GIN SB RAS. (in Russian)

[7] Frank-Kamenetskiy, V. A. 1983. X-Ray Diffraction of the Main Types of Rock-Forming Minerals. Leningrad: Publishing House "Nedra".

[8] Jeffery, P. 1973. Chemical Methods of Analysis of Rocks. Moscow: Publishing House "Mir". (in Russian)

[9] OST 41-08-212-04. 2004. Industrial Standard. Quality Control of Analytical Works. Moscow: Russia Scientific Institute of Mineral Resources. Standardinform Press. (in Russian)

[10] Service Manual. S8 TIGER XRF Spectrometer, 2007. Bruker AXS, Berlin.
[11] Youn-Tae, K., Junseok, L., Hye-On, Y., and Nam-Chil, W. 2016. "Determination of Sulfur in Soil and Plant MEDIA Using Wavelength Dispersive X-Ray Fluorescence Spectrometry as a Tool for Assessment of Chemical Spills." Microchemical Journal 124: 594-9.

[12] Khudonogova, E. V., Revenko, A. G., Akulova, V. V., and Shtel'makh, S. I. 2005. "Development of the Technique for the Determination of Phosphorus Oxide, Sulfur and Chlorine in Soils and Sedimentary Rocks by the X-Ray Fluorescence Method." In Structure, Functioning and Evolution of Mountain Landscapes of the Western Baikal Region. Irkutsk: Publishing house of the Sochava Institute of Geography SB RAS. (in Russian)

[13] SPECTRA ${ }^{\text {plus }}$. Software package for X-Ray Spectrometers. Version 2.2.3.1, 2010. Bruker AXS, Karlsruhe.

[14] Arnautov, N. V. 1990. Reference Materials of the Chemical Composition of Natural Materials. Novosibirsk: Publishing House "Nauka". (in Russian)

[15] Govindaraju, K. 1994. "Compilation of Working Values and Sample Description for 383 Geostandards." Geostandards and Geoanalytical Research 18: 1-158.

[16] Revenko, A. G. 1994. X-Ray Spectral Fluorescence Analysis of Natural Materials. Novosibirsk: Publishing House "Nauka". (in Russian)

[17] Kartasheva, E. V., and Sadovnikova, A. O. 2008. "First Step of Elaboration of the Method of Determination of Concentration of Chlorine in Rocks and Minerals by the X-Ray Fluorescence Analysis.” Messenger Kraunz. Earth Sciences 12 (2): 135-40.

[18] Cherkashina, T. Y., Shtel'makh, S. I., and Pashkova, G. V. 2017. "Determination of Trace Elements in Calcium Rich Carbonate Rocks by Wavelength Dispersive X-Ray Fluorescence Spectrometry for Environmental and Geological Studies." Applied Radiation and Isotopes 130: 153-61.

[19] Rousseau, R. M. 2001. "Detection Limit and Estimate of Uncertainty of Analytical XRF Results." The Rigaku J. 18: 33-47.

[20] Margui, E., Hidalgo, M., and Queralt, I. 2005. "Multielemental Fast Analysis of Vegetation Samples by Wavelength Dispersive X-Ray Fluorescence Spectrometry: Possibilities and Drawbacks." Spectrochim. Acta. Part B 60: 1363-72. 